\title{
Genetic Variability for Frost Resistance Among Coffea Accessions Assessed in the Field and in a Cold Chamber
}

\author{
Marcos Rafael Petek, Tumoru Sera ${ }^{*}$ and Marcos Zorzenon Alteia \\ Instituto Agronômico do Paraná - IAPAR; Área de Genética e Melhoramento; Rod. Celso Garcia Cid; KM 375; \\ C. P. 481; 86.001-970; tsera@iapar.br; mrpetek@pop.com.br; Londrina-PR - Brazil
}

\begin{abstract}
The genetic variability for frost resistance was evaluated in field conditions and cold chamber among Coffea accessions. Results showed that $\underline{C}$. liberica var. dewevrei and $\underline{C}$. racemosa, as well as hybrids obtained from these species were more resistant to frost. There was a great genetic variability for frost resistance among the evaluated sources $\left(b^{2}=0,98\right)$. The correlation estimated between damages in the field and in the cold chamber was $0.933 * *$, therefore, this methodology was efficient and feasible and could be potentially used in a breeding program.
\end{abstract}

Key words: Coffee crop, breeding, frost resistance, cultivar

\section{INTRODUCTION}

Severe frosts that occur every 5 or 6 years in practically all the coffee growing regions of Paraná, São Paulo and South Minas Gerais (Caramori and Manetti Filho, 1993) make the activity unstable. This phenomenon was one of the main reasons that discouraged Paraná coffee growers and caused the consequent gradual eradication of the coffee plantations, especially after the 1975 frost that damaged nearly all the coffee growing area in the state when it was the main producer in Brazil, yielding more than 20 million bags in about 1,800,000 ha (Lima, 1989). Coffee is mostly cultivated by small and medium sized producers who survive in this activity and also create direct and indirect employment. The development of cultivars more resistant to frost would be socially and also economically important because coffee is still one of the main agricultural activities in Brazil.
Whether there is genetic variability for frost resistance in coffee, that is essential for a successful breeding program, is fairly controversial, especially because Coffea spp. originated in tropical climate regions and therefore would not have genetic variability for frost resistance.

Genetic variability for frost resistance in Coffea species and among $C$. arabica accessions has already been reported. These include $C$. racemosa (Paraná Agronomic Institute Foundation, 1978; Söderholm and Gaskins, 1981; Sentelhas et al., 1995; Triller et al., 2001) and C. liberica var. dewevrei (Fundação Instituto Agronômico do Paraná, 1978; Sentelhas et al., 1995; Triller et al., 2001) as most frost resistant. The existence of variability among $C$. arabica cultivars has also been reported (Caramori and Sera, 1979; Sera, 2001; Androcioli Filho et al., 1986; Söderholm and Gaskins, 1981; Bauer et al., 1990; Sentelhas et al., 1995; Triller et al., 2001).

\footnotetext{
* Author for correspondence
} 
Camargo and Salati (1966) studied seedlings and leaves of young coffee trees exposed in frosty nights and indicated that the first leaf damage appeared at temperature of approximately $-2^{\circ} \mathrm{C}$ and that serious, generalized damage only occurred when the temperature fell below $-3{ }^{\circ} \mathrm{C}$. Ferraz (1968) and Manetti Filho and Caramori (1986) obtained similar results and also showed that there was interaction between temperature and exposure time for the damage to worsen. Ferraz (1968) showed that the lethal temperature for coffee tree leaves was very close to freezing. This indicated that arabic coffee plants presented resistance but not tolerance, occording to the definition by Levitt (1980).

An methodology under controlled conditions is fundamentally important for a coffee genetic breeding program to be efficient in selecting coffee plants more resistant to frost and not become dependent on the occurrence of the phenomenon in the field for assessment and selection. Studies by Ferraz (1968), Manetti Filho and Caramori (1986) and Sentelhas et al. (1995) for assessing coffee plants seedlings in a cold chamber are references of assessment methodology of cold resistance usable in a breeding program. The study by Camargo and Salati (1966) that consisted of carrying out, side by side under natural conditions, thermal determinations and observations on samplings and leaves removed from young trees indicated that the method of exposing excised leaves was satisfactory because the results were similar on removed leaves and leaves still on the plants.

Coffee genetic breeding requires a long time to obtain a cultivar (Sera, 2001). The use of coffee trees in the juvenile stage to assess frost resistance under controlled conditions is important, but the development time of the seedlings must elapse. Frost resistance behaves differently in coffee trees with and without production (Carvalho, 1988; Sera and Guerreiro, 1995; Petek et al., 2002). The objective of this study was to assess the variability for frost resistance among Coffea accessions by an assessment methodology that used leaves sampled on adult trees in the field so as not to depend on natural frost occurrence.

\section{MATERIAL AND METHODS}

Coffea accessions were used from Germplasm Bank II at IAPAR, Londrina Production and Experimentation Center with a mean annual temperature of $20.8{ }^{\circ} \mathrm{C}, 585$ meters above sea level, latitude $23^{\circ} 22^{\prime} \mathrm{S}$ and longitude $51^{\circ} 10^{\prime} \mathrm{W}$ in field blocks without an experimental design with the single objective of maintaining the genetic materials. It consists of species, hybrids and accessions from other institutions and has species indicated as more frost resistant, susceptible and some cultivar accessions. The materials used in this study are presented in Table 1.

\section{Assessment Methodologies}

(a) Under field conditions

This assessment was carried out for exploratory purposes because the germplasm bank did not had a statistical design. Each germplasm, consisting of 5 to 10 plants, was assessed after the severe frost of July 2000 (minimum temperature in the meteorological shelter $-1.3{ }^{\circ} \mathrm{C}$ ). The damage was assessed according to a scale of scores ranging from 1 to $5: 1=0 \%$ damage; $2=25 \%$ damage; $3=$ $50 \%$ damage, $4=75 \%$ damage $5=100 \%$ damage, adjusted for adult plants from the scale used by Manetti Filho and Caramori (1986) to assess damage in shoots.

Table 1 - Description of the treatments (T) of Germplasm Bank II at IAPAR

\begin{tabular}{|c|c|}
\hline $\mathbf{T}$ & Genotypes \\
\hline 1 & Coffea canephora var. kouillou $($ Control $1=\mathrm{C} 1)$ \\
\hline 2 & "Arabusta" (C. arabica x C. canephora var. robusta) $(4 \mathrm{n})$ \\
\hline 3 & C. liberica var. dewevrei \\
\hline 4 & C. racemosa \\
\hline 5 & "Piatã" ((C. liberica var. dewevrei $\times$ C. arabica $) \times$ C. arabica $)$ \\
\hline 6 & "Triplóide" (C. arabica x C. racemosa) \\
\hline 7 & C. arabica cv. Caturra Amarelo \\
\hline 8 & C. arabica cv. Geisha \\
\hline 9 & C. arabica cv. Acaiá IAC 474-7 (Control 2 = C2) \\
\hline
\end{tabular}


(b) in the cold chamber

Leaves were sampled for each treatment used in this study by collecting 20 leaves from each treatment, selecting the leaves of the third pair, distributed homogeneously for all the plants, always on the same side so that possible sampling errors were minimum.

The leaves were collected in the morning, placed immediately in plastic bags and closed. After collection, the leaves were fixed by the petiole in recipients containing moist sand so that they remained in a vertical position.

The experiment was set up in a randomized complete block design with 9 treatments (Table 1), three replications and five leaves per plot. The cold chamber was turned on without ventilation and a plastic support was installed in the upper part of the experiment and below the cold air exit so that the cold air flowed the most evenly possible over the experiment with the sampled leaves. Previous observations showed that with the chamber turned on without ventilation, the temperature on the surface measured with a thermal hygrograph, was approximately $1.5{ }^{\circ} \mathrm{C}$ lower than that indicated by the cold chamber probe. Therefore, the temperature was always regulated considering this difference. The chamber was turned on at 5 p.m. and adjusted to $+3.5{ }^{\circ} \mathrm{C}$ $\left(+2{ }^{\circ} \mathrm{C}\right.$ on the thermal hygrograph). This temperature was attained two hours later and maintained for the rest of the night. At 8 a.m. the next day the cold chamber was regulated to $-2{ }^{\circ} \mathrm{C}$ $\left(-3.5{ }^{\circ} \mathrm{C}\right.$ on the thermal hygrograph) that was attained approximately $3 \mathrm{~h}$ later. This temperature was maintained for a further three hours and then the chamber was turned off and the door kept shut so that the temperature would rise slowly, recorded on the thermal hygrograph. The air humidity throughout the experiment was between 80 and $90 \%$. After $24 \mathrm{~h}$, when the damage was quite pronounced, the leaves were assessed according to a scale of scores, $1=0 \%$ damage; $2=$ $10 \%$ damage; $3=20 \%$ damage; $4=30 \%$ damage; $5=40 \%$ damage; $6=50 \%$ damage; $7=60 \%$ damage; $8=70 \%$ damage; $9=80 \%$ damage and $10=>90 \%$ damage.

\section{Statistical analysis}

(a) Data obtained in the field.

The frost damage means (GOO) and the variance were estimated for each treatment. All the estimates were carried out by the Genes statistical program (Cruz, 2001). (b) Data obtained in the cold chamber.

The test of normality was carried out by the method proposed by Tukey (1949) quoted by Ramalho et al. (2000) that estimates and tests the sum of the squares of the non-additivity. The mean square of the non additivity was significant at $1 \%$ probability by the $\mathrm{F}$ test, therefore, one of the assumptions of analysis of variance, that the effects of treatments and environment should be additive, was not satisfied. The method proposed by Ascombe and Tukey (1963) and quoted by Ramalho et al. (2000) was applied and showed that there is heterogeneity of variances and a linear association between the plot mean and its associated error. According to Steel and Torrie (1980) when the effects are not additive and there is a relationship between the mean and the variance, logarithmic transformation solves the problem. Therefore the original data of the leaf assessment in the cold chamber were transformed to $\log _{10}(X+1)$.

Analysis of variance was carried out with the transformed data and the following genetic parameters were estimated: phenotypic variance $\left(\mathrm{s}^{2}{ }_{\mathrm{p}}=\mathrm{QM}_{\text {gentypes }} /\right.$ blocks $)$, genotypic variability $\left(\mathrm{s}_{\mathrm{g}}{ }^{2}=\mathrm{QM}_{\text {gentypes }}-\mathrm{QM}_{\text {error }} /\right.$ blocks $)$, coefficient of genotypic determination $\left(b^{2}=s^{2}{ }_{g} / s_{p}^{2}\right)$ and coefficient of genetic variation $(\mathrm{CVg} \%=100 \mathrm{~s} g$ /mean).

The means of the treatments were compared by the Tukey test at 5\% probability. The Spearman coefficient of correlation was further estimated between the mean damage obtained in the field and the mean damage obtained in the leaf assessment in the cold chamber. All the estimates, except the analysis of normality of the damage and the homogeneity test of the variances, were carried out by the Genes statistical program (Cruz, 2001).

\section{RESULTS AND DISCUSSION}

\section{Field assessments}

The $C$. racemosa and "Triploide" $(C$. arabica $\times$ C. racemosa) accessions presented mean damage of 1.0 and 0.0 variance. No damage was detected in any of the plants in these two treatments, confirming the results in the literature (Fundação Intituto Agronômico do Paraná, 1978; Söderholm and Gaskins, 1981; Sentelhas et al., 1995) that greater frost resistance was conferred by this species within the Coffea genus. 
The $C$. liberica var. dewevrei and the "Piatã" $((C$. liberica var. dewevrei $\times$ C. arabica) х $C$. arabica) accessions presented mean damage of 1.17 and 2.33 , respectively, indicating that they were less frost resistant than $C$. racemosa and "Triploide" (C. arabica x C. racemosa), but had a higher level of resistance than $C$. arabica accessions such as obtained by Sentelhas et al. (1995). "Piatã", as expected, because it had more $C$. arabica genes, was more frost susceptible than $C$. liberica var. dewevrei.

The $C$. arabica accessions 'Geisha', 'Caturra Amarelo', and 'Acaiá IAC 474-7' (C2) showed an intermediate level of frost resistance, with mean damage of 3.0, 3.67 and 3.76, respectively. These results were in line with those obtained by Bauer et al. (1990) regarding the Geisha cultivar being more resistant than the Caturra cultivar.
The most susceptible genotypes were "Arabusta" (C. arabica x C. Canephora var. robusta) and $C$. canephora var. kouillou (C1) with mean damage of 4.17 and 4.75, respectively. Although they presented little difference, the lower mean damage to "Arabusta", that has more C. arabica genes, as was expected.

\section{Assessment in the cold chamber}

The analysis of variance (Table 2) showed that the effects of blocks and genotypes were significant at $1 \%$ probability by the $\mathrm{F}$ test. The significance of blocks proved the need to use this design, even inside the cold chamber, where the conditions are apparently homogeneous. The significant genotype effect showed the existence of variability among the nine genotypes used in this study and consequently within the Coffea genus.

Table 2 - Analysis of variance and genetic parameters of frost resistance assessed in the experiment with leaves from Coffea species, hybrids and cultivars in cold chamber.

\begin{tabular}{lcc}
\hline \multicolumn{1}{c}{ Source of Variation } & D. F. & Mean Squares \\
\cline { 3 - 3 } & 2 & DF $^{1}$ \\
Blocks & 8 & $0,086^{*}$ \\
Genotypes & 16 & $0,114^{*}$ \\
Error & & 0,002 \\
\hline Mean & & 0,58 \\
Mean (original data) & 3,25 \\
CVe\% & 8,25 \\
\hline Parâmetros Genéticos & \\
\hline $\mathrm{s}^{2}$ Phenotypic & 0,038 \\
$\mathrm{~s}^{2}$ Genotypic & 0,037 \\
$\mathrm{~b}^{2}$ & 0,98 \\
CV\% Genetic & 33,39 \\
CVg(\%)/CVe(\%) & 4,04 \\
\hline
\end{tabular}

*Significant at $1 \%$ probability by the $\mathrm{F}$ test

${ }^{1}$ Mean leaf damage caused in the cold chamber (data transformed by $\log _{10}(\mathrm{x}+1)$ ).

The mean leaf damage was 3.25 (Table 2) and more pronounced leaf damage was expected because the leaves remained at $-3.5^{\circ} \mathrm{C}$ for three hours. The high humidity inside the cold chamber could have been the cause limiting the effect of cell dehydration and later cell death (Steponkus et al., 1998; Steponkus et al., 1993) by supplying a high water content in the intercell spaces, consequently causing less fall in the water potential outside the cell and less water migration from inside to outside the cell.

The coefficient of experimental variation was $8.25 \%$ (transformed data) (Table 2). Therefore, there was good experimental accuracy that consequently showed the high potential of using this methodology to assess cold resistance in segregant progeny in a genetic breeding program. The estimated coefficient of genotypic determination $\left(\mathrm{b}^{2}\right)$ was 0.98 (Table 2 ), that is, $98 \%$ of the variation among the germplasms used in this study was determined by genetic factors. Therefore there is great variability for frost resistance.

Table 3 shows the results of the mean leaf damage assessment in the cold chamber and the Tukey test for comparing these means. The $C$. racemosa accessions, "Triploide", "Piatã", 'Geisha', $C$. liberica var. dewevrei and $C$. arabica cv. Caturra 
Amarelo presented mean damage ranging from 1.54 to 2.36 and did not differ by the Tukey test at $5 \%$ probability. This analysis showed unexpected results because it classified the Geisha and Caturra Amarelo cultivars at the same level of leaf damage as $C$. racemosa and $C$. liberica var. dewevrei, described in the literature as more resistant (Fundação Instituto Agronômico do Paraná, 1978; Söderholm and Gaskins, 1981; Sentelhas et al., 1995). However, it should be considered that there could have been possible problems in the sampling. A possible explanation could be large morphological diversity among the genotypes, especially regarding $C$. liberica var. dewevrei that has larger leaves and denser canopies than the others so that more shaded leaves could have been sampled that were, therefore, more susceptible to cold, as described by Triller et al. (2001) making interpretation difficult. Another possible problem in the interpretation of the results may be due to the fact that homogeneous and representative samples of leaves for yield and vigor are difficult to obtain. This did not imply discredit for this methodology for $C$. arabica segregant progeny selection, but all the possible variables assessed in the field that could influence to a greater or lesser degree must be considered.

The 'Acaiá IAC 474-7' (C2) accession showed medium leaf damage of 3.78 and was significantly more susceptible by the Tukey test at $5 \%$ than all the other genotypes of the group that included $C$. racemosa and $C$. liberica var. dewevrei and more resistant than the "Arabusta" and $C$. canephora var. kouillou (C1) with mean leaf damage of 5.89 and 7.89 , respectively, classified as the most susceptible to frost. Again, in spite of the equal statistics, the mean damage was less in "Arabusta" than in C. canephora var. kouillou because of the greater quantity of $C$. arabica genes.

These results are in line with reports by the Fundação Instituto Agronômico do Paraná (1978), Caramori and Sera (1979), Söderholm and Gaskins (1981), Bauer et al. (1990), Sentelhas et al. (1995), Sera (2001) and Triller et al. (2001).

Table 3 - Tukey test to compare means of the experiment with Coffea species, hybrid and accession leaves in the cold chamber and mean damage in the field caused by the frost in July 2000.

\begin{tabular}{|c|c|c|}
\hline Treatments & $\mathrm{DF}^{1}$ & $\mathrm{G00}^{2}$ \\
\hline C. racemosa & 1,54 & 1,00 \\
\hline "Triplóide" (C. arabica x C. racemosa) & 1,61 & 1,00 \\
\hline "Piatã" ((C. liberica var. dewevrei x C. arabica $)$ х C. arabica $)$ & 1,89 & 2,33 \\
\hline C. arabica cv. Geisha & 2,00 & 3,00 \\
\hline C. liberica var. dewevrei & 2,33 & 1,17 \\
\hline C. arabica cv. Caturra Amarelo & 2,36 & 3,67 \\
\hline C. arabica cv. Acaiá (Control 2) & 3,78 & 3,76 \\
\hline "Arabusta" (C. arabica X C. canephora var. robusta) $(4 \mathrm{n})$ & 5,89 & 4,17 \\
\hline Coffea canephora var. kouillou (Control 1) & 7,89 & 4,75 \\
\hline Média & 3,25 & 2,76 \\
\hline
\end{tabular}

Coeficiente de Correlação de Spearman $^{3}=0,933 * *$

Means (original data) followed by the same letter (obtained in the Tukey test with transformed data) on the vertical do not differ by the Tukey test at $5 \%$.

${ }^{1}$ mean leaf damage caused in the cold chamber (scores 1 to 10 (original data) where $1=$ absence of leaf damage

${ }^{2}$ Mean damage caused by the frost in July 2000 (Scores 1 to 5 were $5=$ totally burnt)

${ }^{3}$ Spearman coefficient of correlation between leaf damage in the cold chamber and in the field.

\section{Correlation between frost damage in the field and damage in the cold chamber}

The Spearman correlation coefficient (Table 3) estimated between the mean damage assessed from frost in the field in 2000 and the mean leaf damage obtained in the assessment in the cold chamber was 0.933 , significant at $1 \%$ probability by the t test. C. liberica var. dewevrei was the only genotype that changed classification according to mean leaf damage in the cold chamber compared with frost damage in the field that could also have been due to possible sampling problems already referred previously. This assessment methodology for frost resistance using leaves sampled from plants established under field conditions was efficient and practical, with potential for use in a breeding program for frost resistance. It could be an important tool in obtaining coffee cultivars with 
enough resistance to the prevailing frosts in the traditional cultivation regions of Paraná and other producer states located in frost areas, decreasing the instability of the activity.

\section{ACKNOWLEDGEMENTS}

The authors thank the coffee plant breeding team at the Agronomic Institute of Paraná (IAPAR) for developing the studies, the Brazilian Consortium for Coffee Research and CAPES for financial support, and the Master of Science Program in Genetics and Plant Breeding at State University of Londrina.

\section{RESUMO}

A variabilidade genética para resistência à geada foi avaliada em campo e em câmara fria entre acessos de Coffea. Os resultados mostraram que $C$. liberica var. dewevrei e $C$. racemosa e os híbridos derivados delas foram mais resistentes à geada. Existe grande variabilidade genética para resistência à geada entre estes materiais genéticos estudados $\left(b^{2}=0,98\right)$. A correlação obtida entre as médias de dano foliar no campo e na câmara fria foi de 0,933**. Esta metodologia é eficiente e prática, com potencial de utilização em um programa de melhoramento para resistência à geada.

\section{REFERENCES}

Androcioli Filho, A.; Siqueira, R.; Caramori, P. H.; Pavan, M. A.; Sera, T. and Soderhölm, P. K. (1986), Frost injury and performance of coffee at $23^{\circ} \mathrm{S}$ in Brazil. Experimental Agriculture, 22, 71-74.

Bauer, H.; Comploj, A. and Bodner, M. (1990), Susceptibility to chilling of some Central African cultivars of Coffea arabica. Field Crops Research, 24 : (1), 119-129.

Camargo, A. P. and Salati E. (1966), Determinação da temperatura letal de folhagem de cafeeiro em noite de geada. Bragantia, 25, 61-63.

Caramori, P. H. and Manetti Filho, J. (1993), Proteção dos cafeeiros contra geadas. Londrina : IAPAR, (IAPAR. Circular, 79). pp. 28.

Caramori, P. H. and Sera, T. (1979), Influência do porte do cafeeiro no dano provocado por geada. In: Congresso Brasileiro de Pesquisas Cafeeiras, 7., Araxá - MG. Anais... Araxá - MG.
Carvalho, A. (1988), Principles and Practices of Coffee Plant Breeding for Productivity and Quality Factors: Coffea arabica. In: Clarke, R. J. and Macrae R. (Eds.). Cofee. London : Agronomy, Elsevier Applied Science. pp. 129-165.

Cruz, C. D. (2001), Programa GENES - Aplicativo computacional em genética e estatística. Universidade Federal de Viçosa, Viçosa, MG.

Ferraz, E. C. (1968), Estudos sobre o momento em que a geada danifica as folhas do cafeeiro. Tese de Doutorado, Piracicaba, ESALQ/USP.

Fundação Instituto Agronômico do Paraná. (1978), Relatório Técnico Anual. Londrina, PR. pp. 265.

Levitt, J. (1980), Responses of plants to environmental stresses. In: Chilling, Freezing and High Temperature Stresses. $2^{\text {th }}$ ed. New York: Academic.

Lima, F. B. (1989), Café no Paraná, diagnóstico da cultura, análise e perspectivas. Cafeicultura Moderna, $2:$ (7), 22-25.

Manetti Filho, J. and Caramori, P. H. (1986), Desenvolvimento de uma câmara para simulação de temperaturas baixas. Pesquisa Agropecuária Brasileira, 21 : (10), 1005-1008.

Petek, M. R.; Sera, T.; Altéia, M. Z.; Azevedo, J. A.; Triller, C. F. and Sérgio, F. (2002), Análise de trilha entre caracteres agronômicos e dano de geada, em progênies derivadas do cruzamento "Vila Sarchi" $\mathrm{x}$ "Híbrido de Timor". SBPN-Scientific Journal, 6 : (Esp.), 37-39.

Ramalho, M. A. P.; Ferreira, D. F. and Oliveira, A. C. (2000), Princípios básicos da experimentação e suas implicações na genética e no melhoramento de plantas. In: A experimentação em genética $e$ melhoramento de plantas. UFLA, Lavras. pp. 41-50.

Sentelhas, P. C.; Fazuoli, L. C. and Pezzopane, J. R. M. (1995), Temperatura letal de diferentes espécies e derivados de híbrido interespecífico de café. In: Congresso Brasileiro de Pesquisas Cafeeiras, 21., Caxambu - MG. Anais... Caxambu - MG.

Sera, T. and Guerreiro, A. (1995), Correlação entre o dano de geada e outras características agronômicas em linhagens de café (Coffea arabica L.). In: Simpósio sobre Caficultura Latino Americana, 17., Fundacion Salvadoreña para Investigaciones del Café. San Salvador. Anais... San Salvador.

Sera, T. (2001), Coffee genetic breeding at IAPAR. Crop Breeding and Applied Biotechnology, 1 : (2), 179-190.

Söderholm, P. K. and Gaskins, M. H. (1981), Evaluation of cold resistance in the genus Coffea. Indian Coffee, 45 : (5), 123-128.

Steel, R. G. D. and Torrie, J. H. (1980), Analysis of variance II: Multiway classifications. In: Principles and procedures of statistics. New York : McGrawHill Book. pp. 132-160. 
Steponkus, P. L.; Uemura, M.; Joseph, R. A.; Gilmour, S.J. and Thomashow M. F. (1998), Mode of action of the COR15a gene on the freezing tolerance Arabidopsis thaliana. Proceedings National Academic Science, 95, pp. 14570-14575.

Steponkus, P. L.; Uemura, M. and Webb, M. S. (1993), Membrane destabilization during freeze-induced dehydratation. Current Topics Plant Physiology, 10, pp. 37-47.

Triller, C.; Sera, T.; Petek, M. R. and Azevedo, J. A. (2001), Avaliação da resistência à geada, em câmara fria, de diferentes espécies de café. In: Simpósio de Pesquisa dos Cafés do Brasil, 2., Vitória - ES. Anais... Vitória - ES.

Received: May 19, 2003; Revised: February 05, 2004; Accepted: July 09, 2004. 